\title{
INO80D wt Allele
}

National Cancer Institute

\section{Source}

National Cancer Institute. INO80D wt Allele. NCI Thesaurus. Code C125259.

Human INO80D wild-type allele is located in the vicinity of 2 q33.3 and is approximately 93 $\mathrm{kb}$ in length. This allele, which encodes INO80 complex subunit D protein, is involved in chromatin remodeling. 